\title{
The significance of ' $I$ ' in educational research and the responsibility of intellectuals
}

\author{
Jean McNiff \\ jeanmcniff@mac.com
}

\begin{abstract}
In this paper I call for an unequivocal legitimisation of the living 'I' in educational research. The paper itself becomes a context that explains this call. It is a report of my action research into my professional learning through working in South Africa, within the context of new policy frameworks for continuing teacher development. The call embeds issues about the need for higher education practitioners to produce their explanatory accounts of practice as they support teachers' enquiries for improving practice and knowledge creation, and to legitimise a free academic press for the dissemination of those accounts. The accounts need to demonstrate epistemological, methodological and scholarly validity, to strengthen practitioners' attempts to influence policy debates about continuing professional development. By clarifying the processes of establishing quality, it becomes possible to show the links between continuing professional education and the active contributions of practitioners to economic and social wellbeing.
\end{abstract}

Keywords: academic freedom; epistemological accountability; living educational theories; practitioner enquiry; professional learning in higher education

\section{Introduction}

This paper is an explanatory account of my professional learning within the context of supporting practitioners' action enquiries for higher degree accreditation. I believe that the ideas expressed here are contributing to an influential international lobby for the legitimisation of a new epistemology of educational knowledge that places the living 'I' at the centre of educational research. In the paper I explain how this claim may be tested and validated.

I first set out the frameworks for my text. Because the paper is a research account, I organise it using the same kind of questions that provide a methodological framework for the research, as follows.

- What is my concern?

- Why am I concerned?

- What kind of examples can I produce to show the situation as it is and as it develops?

- What can I do about it? What will I do about it?

- How will I ensure that any conclusions I come to are reasonably fair and accurate?

- How do I explain the potential significance of my research?

- How do I modify my practice and ideas in light of my evaluation? (see Whitehead, 1989). 
Here is my research report.

\section{What is my concern?}

I am concerned about the exclusion of the living 'I' (Whitehead, 1989) in dominant forms of educational research. This exclusion is worrying, given international trends towards the development of new epistemologies for a new scholarship (Schön, 1995) and the generation of living forms of theory (Whitehead, 1989), communicated through the narrative accounts of real people. I am also concerned that the exclusion of the 'I' becomes a key factor in what amounts to a literary orthodoxy, and which inevitably influences the decisions of journal editors about which accounts to publish. This can be especially problematic for an editor when faced with high quality work that does not conform to an established style, as Donmoyer (1996) noted when he asked, 'What's a journal editor to do in an era of paradigm proliferation?' It is well known that these influential orthodoxies exist, as demonstrated in the following comment about philosophical writing.

Contemporary philosophical writing is largely impersonal and technical in style. It proposes definitions, makes arguments, criticizes other arguments, corrects previous infidelities and imprecisions in a position, and situates it all in a context of issues current in the discipline ... The writing of philosophy is now measured by professional standards. Those standards specify that, even where a text is not yet presented in a clear, impersonal and argumentative form, it should, in principle, be translatable into one (Mathien \& Wright, 2006:1; 3).

This is not how I, or many other researchers, understand or practise philosophical writing. My understanding, following Code (1987), is that knowledge is generated by a knowing subject, from within a social context, and this is best communicated through narrativised accounts that tell the story of one's learning. According to the norms of the canon, however, my texts, including the one you are reading, would not be recognised as valid.

While I am dismayed by the exclusion of the living 'I' from dominant educational research discourses, I am even more dismayed by the willingness of so many of the educational research community to go along with the situation that effectively eliminates the subjective personal knowledge of practitioners from educational discourses, in spite of comprehensive evidence that shows how practitioners are actively contributing to cultural, social and political transformation through their scholarly accounts of practice (see www.actionresearch.net and www.jeanmcniff.com). I am dismayed by the insistence on an abstract authorial positioning in research accounts, a view from nowhere' (Nagel, 1986), that assumes that accounts simply appear without the active agency of the writer. Given the amount of literary criticism about the poverty of abstractions from reality (Derrida, 1986) and their tendency to contain subtle forms of colonisation (Said, 1991; Todorov, 1995), it is amazing that so many should hold on to literary forms that are becoming outmoded shibboleths. 
The main reason for my dismay is, however, in the demonstration by some researchers of a lack of what Code (1987) calls epistemic responsibility, or intellectual virtue, a commitment to substantive knowledge without critical reflection on the origin, nature and use of the knowledge in question:

Intellectual virtue is, above all, a matter of orientation toward the world, toward one's knowledge-creating self, and toward other such selves as part of the world ... This attitude involves a willingness to let things speak for themselves, a kind of humility toward the experienced world that curbs any excessive desire to impose one's cognitive structurings upon it (Code, 1987:20). I have experienced the effects of this lack of intellectual virtue, for example, when action researchers' reports are judged by assessors who actively maintain their commitments to abstract theory as the allegedly only form of academically legitimate theory. This judgemental stance can easily transform into power-constituted relationships that legitimise the hegemony of higher education-based researchers in making judgements about the capacity of classroom-based teachers to create knowledge. Such processes frequently mean that the rhetoric endorses the development of new living theories, while the practice requires the production of propositional theories. Such contradictions are problematic for Code, for whom intellectual virtue lies in the capacity to 'look at one's (putative) knowledge from the outside, to suspend belief in order to reflect on what one has been doing' (Code, 1987:21). This process is central to action enquiry, akin to Winter's (1989) ideas of reflexive and dialectical critique. An action research account would show that the action researcher has demonstrated epistemic responsibility through personal critique, by showing the capacity to engage with the normative assumptions of their own thinking within a normative research context, and to take remedial action where necessary.

I am perplexed why the living 'I' should continue to be excluded in so much of what passes as educational research, especially in light of President of the British Educational Research Association Geoff Whitty's explanation that perhaps research in education, from a general perspective, should now be called 'education research', while the term 'educational research' should be reserved for research that is educational for the researcher and research participants (Whitty, 2005). I am troubled by how this exclusion is most notable in higher education contexts, given that the Academy still counts as the highest legitimating body of what counts as knowledge, and given that I am a member of the Academy. To maintain the relevance of higher education for people's lives means engaging with new forms of scholarship whose focus is the generation of practitioners' practical theories. Donald Schön made this point in 1995, when he wrote about the need to rethink the kind of epistemologies that are espoused in the modern research university:

If we intend to pursue the 'new forms of scholarship' that Ernest Boyer presents in his Scholarship Reconsidered, we cannot avoid questions of epistemology, since the new forms of scholarship he describes challenge 
the epistemology built into the modern research university (Schön, 1995:27).

I do not offer these comments lightly. I fully appreciate the pressures of the politicised contexts that many higher education personnel work in. I understand the demands, including those of writing for publication, where there are canons, instruction in their use, and the constant pressure of professional publication as an enforcement mechanism' (Mathien \& Wright, 2006:3). I understand these issues from my own experience of them.

Yet while I have sympathy for people working within these politicallyconstituted contexts, I have less sympathy for those who deliberately choose to stay snug within a narrow conceptualisation of academic life, who see their job as recycling and strengthening the existing knowledge base, and producing publications that 'are meant for academic advancement and not for social change' (Said, 1993:53), especially when these publications have little relevance to people less fortunate than themselves. In affluent Dorset, where I live, I see destitute people. In South Africa, where I work, I see people without hope, epitomised by the woman with the baby at the robot. She comes in different skin colours and different clothes yet her face is always the same. I could have been that woman. The woman and her baby should be the proper concerns of educational research, especially in light of what I see as the need to embed education research (research about education) within a wider context of educational research, whose aim should be the transformation of established social and political norms that wilfully tolerate such circumstances. This would, however, mean a shift in identity for many higher education practitioners, from what Foucault (1977) calls the universal intellectual to a specific intellectual, from the generation and application of existing abstract knowledge, carried in propositions, to the generation of new practical knowledge in the public interest, from their workplace contexts. The struggles around 'the truth' are not 'on behalf' of the truth but about the status of truth and the economic and political role that it plays (Whitehead, 1993:18). Said (1993) also makes this point, when, drawing on Gramsci's (1973:13) distinction between the traditional intellectual and the organic intellectual, he maintains that 'the purpose of the intellectual's activity is to advance human freedom and knowledge', and chides those who 'sheepishly go along with the herd,' what Benda (1980:4) referred to as the betrayal of the intellectuals. I recognise that positioning oneself as a specific intellectual can be uncomfortable. Bourdieu (1988) tells how institutional elites ensure academics' compliance with established traditions. I have resisted this, and experienced the whiplash. Yet we are defined by our choices, about which values we espouse and the degree to which we are prepared to live these in our practices, and we accept the consequences of our accountability. I like Marx's critique of Hegel's dialectic with his emphasis on ascending from the Abstract to the Concrete. I also like his point about philosophers only interpreting the world while the point is to change it (Marx, 1845/1998). My own preference is to focus on improving it. In ascending from the Abstract to the Concrete I 
find the creative move in asking, researching and answering questions of the kind, 'How do I improve what I am doing?' The living theories that emerge from such I-enquiries can integrate insights from the most advanced propositional theories of the day without losing a direct contact with the desire to contribute to improvement in one's own practice and in the world.

So, having set out some of my concerns, I now give reasons why they are concerns.

\section{Why am I concerned?}

My first set of reasons is grounded in my ontological, epistemological and pedagogical values, which I consistently try to live in my practice. My ontological values are about the inherent worth of the individual. Like Arendt (1958) and Kristeva (2002), I see persons as individually distinctive, while sharing their singularities. My epistemological values are tested against the empirical work of Chomsky (1986), whose ideas about humans' unlimited creativity in language informs my belief in their unlimited capacity for knowledge creation. My pedagogical values are that people can engage in ongoing transformational learning in processes of social evolution, as expressed by Habermas (1975):

It is my conjecture that the fundamental mechanism for social evolution is to be found in an automatic inability not to learn. Not learning, but not-learning is the phenomenon that calls for explanation at the sociocultural stage of development (Habermas 1975:15, emphasis in original). From this perspective, I see teaching as enabling people to make sense of their learning. This has distinct implications for my pedagogical relationships and strategies. As a teacher I am involved in a dialogical community of equals who are co-creating our knowledge. These values form the bedrock of my identity and my work. Like Fromm (1956), I define my life in terms of my capacity for loving relationships and productive work, and like Said (1993), I define my professional worth in relation to my capacity to speak my truth with integrity, albeit that this may sometimes mean speaking truth to power (Foucault, 1980).

My second set of reasons is grounded in the empirical work of Sen (1999: 8 ), and justifies the reconceptualisation of academic work as directly contributing to social well-being. Sen explains how economic sustainability should be grounded in human freedom, and he foregrounds 'a view of development as an integrated process of expansion of substantive freedoms that connect with one another'. The freedom in question is to do with the exercise of human capacity (1999:292-293).

This view has strong implications for views expressed by, among others, Calderisi (2007), who calls for new political and economic practices in Africa, if Africa is to exercise a credible voice in world affairs. While aid is essential to address deep poverty and lack of resources, he says, and should be given in the short term without necessarily expecting that it should be repaid, it should in the longer term come with expectations that governments will put 
in place infrastructures for people to learn to help themselves. This view links directly with Sen's theory of human capability, and with my own values around identity formation as grounded in loving relationships, productive work and economic well-being. I do not wish anyone to do things for me as long as I am able to do them for myself. Nor do I give to people without expecting them in the longer term to do for themselves. Throughout my professional life, I have always insisted that people should do their own learning; I cannot do it for them. I can arrange appropriate conditions for learning, and I offer unqualified support, yet they must do their work for themselves, and this has to be the basis of our relationships.

So, given these reasons for my concerns, I now produce some baseline data, to show the situation as it is, so that I can imagine possible improvements and how I might realise them.

\section{What kind of examples can I produce to show the situation as it is and as it develops?}

I have learned to interrogate the underpinning epistemologies of the discourses in which I participate. Importantly, I have become critical of my previously uncritical stance, where I used to take as axiomatic the existence of idealised stereotypes of, for example, race and gender. It took hard learning from theorists such as Butler (1999) to bring home to me the counter-productive nature of such stereotyping. It also took hard learning from working in communities where I was positioned as Other to bring home to me the importance of decentring myself (Buber, 1947; McNiff, 2006). So I speak of the capacity to discern underpinning epistemologies from the pain of becoming aware of the colonising power of one's own.

I observe how people in higher education are persuaded to conform to dominant propositional epistemologies (see Waghid, 2005). I observe the gatekeeping practices of many established journals, which exclude the 'I' from scholarly writing, and how such colonising practices share the same epistemological legacy of segregationist regimes. I worry that the Academy itself will increasingly become defined by its exclusionary practices, logics and values, a case not only of denying MacIntyre's (1990) view of the university as a place of constrained disagreement, but also defining it as a product of what Gunter (1995) calls Jurassic management. Perhaps the situation was tolerable while there were no alternatives to traditional forms of scholarship. New forms are however now legitimated, and practitioners' voices have become normative in academic discourses.

However, while arguing for the legitimisation of practitioners' research and their living educational theories, I acknowledge that academic legitimacy has to be earned. It is crucial to maintain high academic standards, and to show the validity of knowledge claims in accounts of practice. Unfortunately, many action researchers do not serve their own emancipatory interests well, and collude in their own subjugation, by not addressing issues of quality in 
the production of research accounts. This understanding gives direction to my own mentoring practices, as I now explain.

\section{What can I do? What will I do?}

Here is an account of what I do.

I work mainly in higher education settings, supporting the action enquiries of practitioner researchers, and the production of their research accounts. I make my own action enquiry public, as I am doing here, as my contribution to a growing knowledge base for systematising and making public the work of teacher researchers (Snow, 2001). Like Whitehead (1999), my aim is to contribute to a reconceptualisation of educational theory as an inclusional form that embraces propositional accounts within its ambit. Thus I see educational research as a living generative transformational process, where each aspect of the research contains the whole within itself, and the whole becomes a manifestation of its parts (Bohm, 1987). I draw on the metaphors of chaos and complexity theory to communicate the idea of self-organising and self-regenerating systems. My work is always in emergence, a process of infinite new beginnings (Said, 1997), as thought influences action, and new action influences the thought in which it is grounded. I encourage practitioners, and myself, to attend to our thinking as much as to our actions in the world. This practice is morally committed, requiring people to justify their practices, as I do in this paper, as their contributions to the public good.

The idea of the good occupies my attention. For an account to be good quality, it needs to demonstrate the validity of what it is claiming. In educational research, in Whitty's (2005) terms, this means that practices contribute to social well-being, within a research frame that demonstrates methodological rigour and dialectical critique (Winter, 1989). This involves the articulation of standards of practice and standards of judgement; and this point brings me to the work of Furlong and Oancea (2005).

Furlong and Oancea explain that action research is internationally legitimated as an impressive form of professional education; it is included in Research Assessment Exercises, with potential to contribute to debates about quality in practice. However, they say, this recognition still does not qualify action research as a form of knowledge creation because the means for making judgements about its quality are not fully theorised or agreed by the action research community, as a prerequisite for legitimacy. Until such agreement is achieved, they say, practitioner researchers must accept that their research accounts will be judged by default in terms of the established criteria and standards of judgement of traditional forms of research.

These challenges have generated responses. Particularly significant is the idea that values can transform into living standards of judgement through their emergence in practice (Whitehead, 2004; Whitehead \& McNiff, 2006). The validity of a claim that practice has improved may be judged evidentially by how well the values that underpin the practice have been realised; and the validity of the claim to methodological rigour can be judged by how far the values informing the enquiry emerge in practice in the creation of new know- 
ledge. If the processes of establishing quality in educational research can be explicated, those understandings may enter into debates about what counts as quality in social living. This would mean that teachers may claim validity for their contributions to social wellbeing, as set out by the Department of Education (2000).

To nurture this potential, I support practitioners in producing accounts that foreground their standards of practice and judgement in testing their evidence-based knowledge claims that they have improved their practices. They make judgements about how well they have realised their ontological, epistemological and pedagogical values in seeking to influence cultural and political transformation; and they also make judgements about how well they have realised their methodological and epistemological values in seeking to influence judgements about the validity of their research. These two processes are intertwined, and are both integral to making judgements about the overall quality of the research account.

To support my claims to educational influence, I draw on work from Ireland (Cahill, 2007; Glenn, 2006; McDonagh, 2007; Roche, 2007; Sullivan, 2006). These accounts are significant because each shows the contribution of teachers to social and cultural transformation through quality research.

Of special relevance for this paper, however, is the database of a group of 13 teachers in Khayelitsha in the Western Cape, whose masters' studies I support. This is a distance learning programme, offered by St Mary's University College, Twickenham, London. Each teacher offers their living theory of research-based practice across a range of issues: raising student achievement (Barnes, 2007; Nokwanele Gungqisa, 2007; Malgas, 2007; Majake, 2007; Mgqweto, 2007; Mpondwana, 2007); improving attendance (Njikelana, 2007); involving parents (Nongwane, 2007); developing co-operative learning (Adams, 2007; Nqabisa Gungqisa, 2007); improving discipline (Blayi, 2007; Ngumbe, 2007) and improving language performance (Pantshwa, 2007). Concurrently I support the masters' studies of seven academic staff at St Mary's, on the same programme and one module ahead. Once published, the work of both groups will contribute to the existing global knowledge base (see www.actionresearch.net and www.jeanmcniff.com).

At the same time as supporting classroom teachers' studies, I work with the Nelson Mandela Metropolitan University, where some 10 academic staff study their practices as professional educators (Olivier, 2007; Wood, 2007). NMMU staff visit the Khayelitsha teachers, and an innovative culture of educational enquiry has developed.

The database shows the processes involved when practitioners make evidence-based judgements about establishing quality in practice and research through testing the validity of knowledge claims. Making value judgements about quality transforms into a form of moral accountability, and establishes the link between the good quality in research and contributions to the social good. 


\section{How do I show that any conclusions I come to are reasonably fair and accurate?}

The question arises whether I demonstrate the same kind of accountability in this account, through testing its validity.

To test my claims to improved workplace practice, I produce evidence from collaborative work, especially with Jack Whitehead of the University of Bath. Its influence is well documented (for example, Moustakim, 2007), and is demonstrated through $\mathrm{PhD}$ living theory completions in a range of universities (for example, Hymer, 2007; Krige, 2007; Steenekamp, 2006), and its uptake in national contexts. The Grand Erie District, Ontario, provides district-wide professional education through action research (Delong, 2002; Delong \& Knill-Griesser, 2006). In the UK, the Training and Development Agency for Schools (TDA) 2007 standards for the teaching profession refer to the need for teachers' research-based explanations for practice (TDA, 2007).

I have explained how my ontological values have emerged through the research as living standards of practice. I have also explained how I demonstrate accountability by showing the transformation of values-based criteria into living epistemological and methodological standards of judgement. I test the validity of my claim by drawing on Habermas's (1976) criteria of social and communicative validity. These criteria state that the account itself should be comprehensible, authentic, truthful and appropriate. By drawing together the separate strands of establishing standards to judge the quality of (1) the practice, (2) the research, and (3) the account, I make a case for the validity and legitimacy of my research account. I exercise epistemic responsibility through dialectical critique, by standing outside my practitioner researcher self and making judgements about the quality of my practice, while acknowledging my intellectual biases within normative cultural contexts. Time will tell whether or not these ideas are taken up more widely, beginning, perhaps, within the creative spaces of educational research in South Africa.

\section{How do I explain the potential significance of my research?}

Gaylard (2005) explains that post-apartheid South Africa is in a postmodern moment, uncertain about how to achieve social sustainability. Yet these moments of destabilisation can offer creative spaces for developing and testing new ideas, which may be an opportunity for the development of the ideas expressed here.

I have explained how practitioners can improve their work and create knowledge by producing explanatory accounts of practice, and by adopting inclusional epistemologies, logics and values (Rayner, 2007; Whitehead, 2006). They explain the significance of their work, and define themselves as morally committed practitioner researchers. They equip themselves to contribute to policy debates regarding research-based professionalism for a good social order.

South Africa is well positioned to demonstrate these links, in light of policy recommendations about teachers as lifelong researchers who can contribute to the well-being of society (Department of Education, 2000), and in light of policy frameworks for continuing professional teacher development 
(CPTD) (Department of Education, 2007). The recommendations state that the South African Council for Educators (SACE) should have 'overall responsibility for the implementation, management and quality assurance of the CPTD system' and that 'SACE will be provided with the necessary resources and support to undertake that role' (ibid.:18). Perhaps SACE and other quality assurance agencies might consider action research-based approaches, which take as axiomatic the need to demonstrate quality in practice and research.

Yet speaking about the continuing professional education of teachers has to be located within debates about the continuing professional education of providers and supervisors, including practitioners in higher education. If academic practitioners are to become providers, they also need to engage in the same processes they are expecting the teachers to engage in. Not to do so, and to remain within the kind of asymmetrical power relationships generated by traditional epistemologies, would involve regressing into divisive forms of social living where power replaces rational debate as the arbiter for making judgements about forms of living. Higher education practitioners therefore also need to demonstrate their methodological and epistemological accountability, by producing their living theories of practice that show how they are encouraging the same kind of accountability within the teaching profession.

This is a feature of my own work, while working with teachers in Khayelitsha (McNiff, 2006). This extraordinary group of teachers is setting precedents for what counts as professionalism in teaching, and communicating this through their accounts. Consider - if they and I can show the processes involved in demonstrating improved quality in practice and research through working as a small group of teachers in a township, who are already influencing the quality of educational experience for their learners, the parents of those learners, and their colleagues, then how much more would be the degree of influence if such initiatives were developed at national level, with adequate resources, and appropriate support and institutional infrastructures.

\section{How do I modify my ideas and practices in light of my evaluation?}

Let me say how I hope to continue this work.

I will continue to engage with the politics of educational knowledge, as I support practitioners from all education sectors in producing their living theories of practice for public legitimation. I intend to find ways of publishing and disseminating those accounts. I will continue to make the case for a free academic press, which, in my view, is vital for democratic forms of research within a democratic political order.

I believe that, like Biko (1978), people should write what they like, but also subject it to the critical scrutiny of educated peers, so that its quality may be judged in terms of social validity (Habermas, 1976, see above), within a context of enlightened scholarly debate. The development of the kind of knowledge that can contribute actively to human well-being has to be nurtured within a context of material 'I's, each willing to listen to the other, and test the validity of their ideas, with humility and respect. I will continue to speak 
for myself, in the company of others who also speak on their own behalf, as a person claiming intellectual originality and exercising her personal judgement responsibly with social intent (Polanyi, 1958:327). We all have choices, and, as intellectuals, the freedom to exercise them. I know what mine are, and what the implications are for demonstrating the quality of my practice.

\section{References}

Adams G 2007. Strategic Planning for Research Project: Module 30PVM08.

Twickenham, St Mary's University College, Twickenham.

Arendt H 1958. The Human Condition. Chicago: University of Chicago Press.

Barnes P 2007. Strategic Planning for Research Project: Module 30PVM08.

Twickenham, St Mary's University College, Twickenham.

Benda G 1980. The Treason of the Intellectuals. Trans. R Aldington. London: Norton.

Biko S 1978. I Write What I Like. Oxford: Heinemann.

Blayi S 2007. Strategic Planning for Research Project: Module 30PVM08.

Twickenham, St Mary's University College, Twickenham.

Bohm D 1987. Unfolding Meaning. London: Ark Paperbacks.

Bourdieu P 1988. Homo Academicus. Cambridge: Polity.

Buber M 1947. Between Man and Man. London: Routledge \& Kegan Paul.

Butler J 1999. Gender Trouble. New York: Routledge.

Cahill M 2007. Towards a living educational theory of inclusional practice. PhD thesis, Limerick, University of Limerick.

Calderisi R 2007. The Trouble with Africa: Why Foreign Aid Isn't Working. New Haven: Yale University Press.

Chomsky N 1986. Knowledge of Language: Its Nature, Origin and Use. New York: Praeger.

Code L 1987. Epistemic Responsibility. Hanover: Brown University Press.

Delong J 2002. How Can I Improve My Practice As A Superintendent of Schools and Create My Own Living Educational Theory? PhD thesis, Bath, University of Bath.

Delong J \& Knill-Griesser H 2006. Passion in Professional Practice: Action Research in Grand Erie, Volume VI. Brantford: Grand Erie School Board.

Department of Education 2000. National Education Policy Act, 1996: Norms and Standards for Educators. Pretoria: Government Printer.

Department of Education 2007. The National Policy Framework for Teacher Education and Development in South Africa. Pretoria: Government Printer.

Derrida J 1986. Of Grammatology. Baltimore, MD: Johns Hopkins University Press.

Donmoyer R 1996. 'Educational Research in an Era of Paradigm Proliferation: What's a Journal Editor to Do?' Educational Researcher, 25:19-25.

Foucault M 1977. 'Intellectuals and Power - A Conversation between Michel Foucault and Giles Deleuze.' In: DF Bouchard (ed.). Michel Foucault, Language, Counter-Memory, Practice. Oxford: Basil Blackwell.

Foucault M 1980. 'Truth and Power.' In: C Gordon (ed.). Power/Knowledge: Selected Interviews and Other Writings, 1972-1977. Brighton: Harvester.

Fromm E 1956. The Art of Loving. New York: Harper \& Row.

Furlong $\mathrm{J}$ \& Oancea A 2005. Assessing Quality in Applied and Practice-based Educational Research: A Framework for Discussion. Oxford: Oxford Department of Educational Studies.

Gaylard G 2005. After Colonialism: African Postmodernism and Magical Realism. Johannesburg: Wits University Press.

Glenn M 2006. Working with collaborative projects: my living theory of a holistic 
educational practice. PhD thesis, Limerick, University of Limerick. Available at http://www.jeanmcniff.com/glennabsract.htm1.. Accessed 2 May 2007.

Gramsci A 1973. The Prison Notebooks: Selections. Trans. Q Hoare \& G Nowell-Smith. London: Lawrence and Wishart.

Gungqisa Nqabisa 2007. Strategic Planning for Research Project: Module 30PVM08. Twickenham, St Mary's University College, Twickenham.

Gungqisa Nokwanele 2007. Strategic Planning for Research Project: Module 30PVM08. Twickenham, St Mary's University College, Twickenham.

Gunter H 1995. 'Jurassic Management: Chaos Theory and Management Development in Educational Institutions'. Journal of Educational Administration, 33:5-20.

Habermas J 1975. Legitimation Crisis. Boston: Beacon Press.

Habermas J 1976. Communication and the Evolution of Society. London: Heinemann.

Hymer B 2007. How do I understand and communicate my values and beliefs in my work as an educator in the field of giftedness? DEdPsy, Newcastle-on-Tyne, University of Newcastle. Avaialble at http://people.bath.ac.uk/edsajw/hymer.shtml. Accessed 17 June 2007.

Krige $\mathrm{H} 2007$. The facilitation of reflection in undergraduate students within the field of Life Orientation. PhD thesis, Johannesburg, University of Johannesburg.

Kristeva J 2002. 'Interview'. Reproduced in J Lechte \& M Margaroni (eds) 2004. Julia Kristeva: Live Theory. London: Continuum.

MacIntyre A 1990. Three Rival Versions of Moral Enquiry: Encyclopaedia, Genealogy, and Tradition. Indiana: University of Notre Dame Press.

Majake T 2007. Strategic Planning for Research Project: Module 30PVM08. Twickenham, St Mary's University College, Twickenham.

Malgas Z 2007. Strategic Planning for Research Project: Module 30PVM08. Twickenham, St Mary's University College, Twickenham.

Marx K 1845/1998. The German Ideology: Including Theses on Feuerbach. Amherst, NY: Prometheus Books.

Mathien T \& Wright D 2006. Autobiography as Philosophy: the philosophical uses of self-presentation. Abingdon: Routledge.

McDonagh C 2007. My living theory of learning to teach for social justice: How do I enable primary school children with specific learning disability (dyslexia) and myself as their teacher to realise our learning potentials? PhD thesis, Limerick, University of Limerick. Available at

http://www.jeanmcniff.com/mcdonaghabstract.html. Accessed 2 May 2007.

McNiff J 2006. Beyond alterity: creating my post-critical living theory of transformational identity. Paper presented at the British Educational Research Association annual meting, University of Warwick, September. Available at http:/ / www.jeanm cniff.com / BERA06/BERA06\% 20Beyond\% 20alterity.htm Accessed 2 May 2007.

Mgqweto A 2007. Strategic Planning for Research Project: Module 30PVM08. Twickenham, St Mary's University College, Twickenham.

Moustakim M 2007. From transmission to dialogue: promoting critical engagement in higher education teaching and learning. Educational Action Research, 15:209220 .

Mpondwana M 2007. Strategic Planning for Research Project: Module 30PVM08.

Twickenham, St Mary's University College, Twickenham.

Nagel T 1986. The View from Nowhere. Oxford: Oxford University Press.

Ngumbe L 2007. Strategic Planning for Research Project: Module 30PVM08.

Twickenham, St Mary's University College, Twickenham.

Njikelana P 2007. Strategic Planning for Research Project: Module 30PVM08. 
Twickenham, St Mary's University College, Twickenham.

Nongwane A 2007. Strategic Planning for Research Project: Module 30PVM08.

Twickenham, St Mary's University College, Twickenham.

Pantshwa M 2007. Strategic Planning for Research Project: Module 30PVM08.

Twickenham, St Mary's University College, Twickenham.

Polanyi M 1958. Personal Knowledge. London: Routledge \& Kegan Paul.

Olivier T 2007. Postgraduate supervision: For better or for worse? A case study.

Working paper, Port Elizabeth, Nelson Mandela Metropolitan University.

Rayner A 2007. Essays and Talks about 'Inclusionality' by Alan Rayner. Available at http://people.bath.ac.uk/bssadmr/inclusionality/. Accessed 17 June 2007.

Roche M 2007. Towards a living theory of caring pedagogy: interrogating my practice to nurture a critical, emancipatory and just community of enquiry. PhD thesis, Limerick, University of Limerick.

Said E 1991. The World, the Text and the Critic. London: Vintage.

Said E 1993. Representations of the Intellectual. London: Vin tage.

Said E 1997. Beginnings: Intention and Method. London: Granta.

Schön D 1995. 'Knowing-in-action: the new scholarship requires a new epistemology'. Change, 27-34.

Sen A 1999. Development as Freedom. Oxford: Oxford University Press.

Snow C 2001. 'Knowing what we know: children, teachers, researchers'. Presidential Address to the American Educational Research Association annual meeting, Seattle. Educational Researcher, 30:3-9.

Steenekamp K 2006. The Improvement of teaching practice in higher education. PhD thesis, Johannesburg, University of Johannesburg.

Sullivan B 2006. A living theory of a practice of social justice: realising the right of Traveller children to educational equality. PhD thesis, Limerick, University of Limerick. Available at http://www.jeanmcniff.com/bernieabstract.html. Accessed 2 May 2007.

Todorov T 1995. The Morals of History. Minneapolis: University of Minnesota Press.

Training and Development Agency for Schools (2007) Draft Revised Professional Standards. Available at http://www.tda.gov.uk/teachers/professionalstandards.aspx. Accessed 3 June 2007.

Waghid Y (ed.) 2005. African(a) Philosophy of Education. Stellenbosch: University of Stellenbosch.

Whitehead J 1989. Creating a living educational theory from questions of the kind, "How do I improve my practice?". Cambridge Journal of Education, 19:41-52. Available at http://people.bath.ac.uk/esajw.writings.livtheory.html. Accessed 2 May 2007.

Whitehead J 1993. The Growth Of Educational Knowledge: Creating Your Own Living Educational Theories. Bournemouth: Hyde.

Whitehead J 1999. How do I improve my practice? Creating a discipline of education through educational enquiry. PhD thesis, Bath, University of Bath. Available at http://people.bath.ac.uk/edsajw/jack.shtml. Accessed 2 May 2007.

Whitehead $\mathrm{J} 2004$. What counts as evidence in the self-studies of teacher education practices? In: JJ Loughran, ML Hamilton, VK LaBoskey \& T Russell (eds). International Handbook of Self-Study of Teaching and Teacher Education. Dordrecht: Kluwer.

Whitehead J 2006. Living Inclusional Values in Educational Standards of Practice and Judgement. Ontario Action Researcher, 8.2.1.

Whitehead J \& McNiff J 2006. Action Research: Living Theory. London: Sage.

Whitty G 2005. Education(al) research and education policy making: is conflict 
inevitable? Presidential Address to the British Educational Research Association, University of Glamorgan, 17 September.

Winter R 1989. Learning from Experience. London: Falmer.

Wood L 2007. What kind of respect is this? Shifting the mindset of teachers regarding cultural perspectives on HIV \& AIDS. Working paper, Port Elizabeth, Nelson Mandela Metropolitan University.

\section{Author}

Jean McNiff is Professor of Educational Research at St Mary's University College, Twickenham; Adjunct Professor at the University of Limerick; and Research Associate at the Nelson Mandela Metropolitan University. She is also a Visiting Professor at Ningxia Teachers University, People's Republic of China. 